Introduction: Breast cancer (BC) in young women of Podkarpackie province accounts for approximately $11.0 \%$ of all diagnosed breast tumors. Aim of the study was to assess the trends in incidence of $B C$ among women younger than 44 from Podkarpackie in the years 2002-2011.

Material and methods: 614 cases of malignant BC and 26 cases of cancer in situ were analyzed. The crude and the standardized incidence ratios were estimated; the percentage of histopathologically confirmed cancer cases and the percentage share of registered malignant breast tumors were calculated. The analysis of incidence in individual counties was also presented, as well as the stages of clinical advancement at diagnosis and the methods of treatment.

Results: The number of registered cases at 2011 was 73, and it was $37.7 \%$ higher as compared to 2002 . During the period analyzed, the in crease in the crude and the standardized cancer incidence ratios was observed. The percentage share of $\mathrm{BC}$ in the examined group increased of $5.4 \%$ in 2011 . Significant variation in incidence among different counties was observed. The incidence ratios ranged from 65.8 to $93.1 / 100000$. BC in young women most commonly was diagnosed as locally advanced and over $70 \%$ of patients were radically treated.

Conclusions: Even though the progress in diagnostics and treatment has been made, BC in young women is diagnosed later than it should be and at considerably advanced stage. It is relevant to propagate the knowledge among women and health professionals to emphasize that $B C$ may affect young women.

Key words: incidence, breast cancer in young women.

Contemp Oncol (Pozn) 2016; 20 (2): 176-184 DOI: $10.5114 /$ wo. 2016.60070

\section{The incidence of breast cancer in population of young women from Podkarpackie province in 2002-2011}

\author{
Aneta U. Radziszewska ${ }^{1}$, Bożenna Karczmarek-Borowska², \\ Monika Grądalska-Lampart ${ }^{1}$, Agata A. Filip ${ }^{3}$
}

\begin{abstract}
${ }^{1}$ Department of Epidemiology and Podkarpackie Cancer Registry, Podkarpackie Oncology Centre, Rzeszow, Poland

2Department of Oncology, Faculty of Medical Sciences, University of Rzeszow, Rzeszow, Poland

${ }^{3}$ Department of Cancer Genetics, Medical University of Lublin, Lublin, Poland
\end{abstract}

\section{Introduction}

Breast cancer (BC) diagnosed in women less than 45 years of age is still a significant challenge in terms of molecular, genetic and psychological studies, and qualifications to oncologic treatment. Diagnostic procedures and treatment algorithms of young BC patients differ considerably in comparison with these dedicated to women who are 45 years old or over. Breast cancer in young women are commonly more aggressive, associated with poor prognosis and are diagnosed at the advanced clinical stage. Early diagnostics in this age group may be difficult. In many cases mammography in young women is not sufficient to identify cancer lesions because of high breast density [1].

According to estimated data presented by Estimated Cancer Incidence, Mortality and Prevalence Worldwide (GLOBOCAN), there were 1676633 cases of malignant breast tumors registered worldwide in 2012, 350126 of new BC cases were diagnosed in women under 44 . Standardized incidence ratios in selected age groups were as follows: for the population of women aged from 15 to 39 was 14.1/100 000, and in the age group 40-44 was $67.2 / 100$ 000. For European population these values were 20.4/100 000 and $102.6 / 100000$, respectively [2]

Breast cancer is the first leading cause of death of malignant cancer in young Europeans - 28.8\%, ant the incidence increases [2]. In United States the invasive BC is diagnosed in approximately 11000 females under 40, which stands for $4.7-4.9 \%$ of all patients with the diagnosis of breast cancer $[3,4]$.

Data presented by the Central Cancer Registry in Korea showed that in 2011 breast cancer was diagnosed in $13.2 \%$ of patients under 40 , and $4.7 \%$ of patients were younger than 35 [5]. The incidence differs up to 4-fold depending on the region of the world and is associated with the ethnic origin of patients. Afro-American females under 35 are twice as more endangered by invasive breast cancer as white females, and the clinical course of the disease is aggressive [1]. The highest incidence ratios were denoted in Australia, North America and Europe, and the lowest in Asia and in the Near East (Table 1).

In Poland, 14649 new cases of breast cancer were registered in females aged between 15 and 44 years in decade 2001-2011. During the analyzed period of time the increase in incidence of $16.6 \%$ was observed. The increase was confirmed by crude and standardized incidence ratios analysis: in 2002 
the respective numbers were $12.5 / 100000$ and 9.0/100 000, while in 2011 - 15.5/100 000 and 10.8/100 000 (Table 2) [6].

The aim of the study is the retrospective analysis of the incidence of malignant breast cancer in young women (under 44 year of life) in Podkarpackie province in 2002-2011.

\section{Material and methods}

In the presented study the population of young patients involved women diagnosed with breast cancer before 44 year of life. There is no clear-cut definition of the term "young patient" in the available scientific literature [7]. Most commonly the term "young" was used for females before 35 years of age [8] or for women before menopause [9].
Material for analyses was obtained from Podkarpackie Cancer Registry in Rzeszow. 614 cases of malignant cancer and 26 cases of cancer in situ diagnosed in young women (up to 44 year of age) from Podkarpackie province in the years 2002-2011 were analysed. The crude and the standardized cancer incidence rates were estimated, the percentage of histopathologically confirmed cancer cases and the percentage share of registered malignant breast tumors in women under 45 years of age compared to all registered malignant $\mathrm{BC}$ cases were calculated. The analysis of incidence in individual counties was also presented, as well as the stages of clinical advancement at diagnosis and the methods of treatment.

Table 1. The estimated incidence of breast cancer in women in the World in 2012 [2]

\begin{tabular}{|c|c|c|c|}
\hline \multicolumn{4}{|c|}{ Breast - estimated incidence } \\
\hline Population & Numbers & Standardized rate (15-39) & Standardized rate $(40-44)$ \\
\hline World & 1676633 & 14.1 & 67.2 \\
\hline Europe & 464202 & 21.6 & 103.3 \\
\hline Northern America & 256222 & 24.8 & 119.2 \\
\hline South America & 115881 & 13.9 & 77.2 \\
\hline Australia & 14710 & 25.7 & 122.5 \\
\hline Asia & 650983 & 12.3 & 55.5 \\
\hline Africa & 133890 & 14.7 & 71.1 \\
\hline Poland & 17259 & 11.1 & 64.4 \\
\hline
\end{tabular}

Table 2. Incidence of breast cancer in Poland in the years 2002-2011 in women under 45 years of age [6]

\begin{tabular}{|c|c|c|c|c|c|c|c|c|c|c|}
\hline \multirow{2}{*}{ 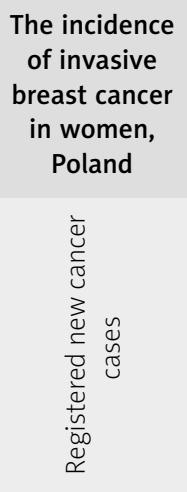 } & \multicolumn{5}{|c|}{$\begin{array}{l}\text { The incidence of invasive breast cancer } \\
\text { in women under } 45 \text { years of age, Poland }\end{array}$} & \multirow{2}{*}{ 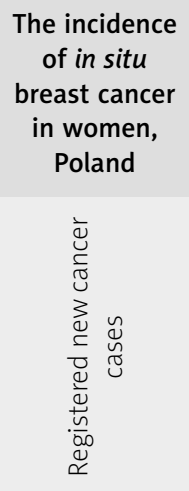 } & \multicolumn{4}{|c|}{$\begin{array}{l}\text { The incidence of in situ breast cancer in } \\
\text { women under } 45 \text { years, of age, Poland }\end{array}$} \\
\hline & 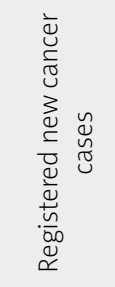 & 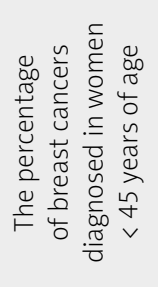 & 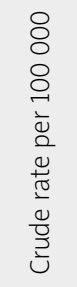 & 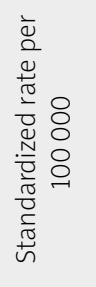 & 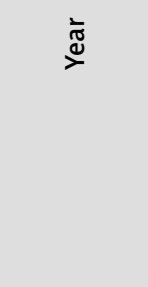 & & 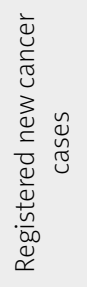 & 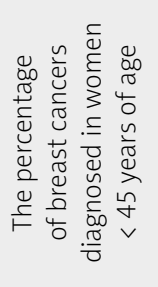 & $\begin{array}{l}8 \\
8 \\
8 \\
8 \\
1 \\
\frac{1}{0} \\
\frac{2}{0} \\
\frac{0}{0} \\
\frac{0}{2} \\
\frac{0}{0} \\
\frac{2}{4}\end{array}$ & 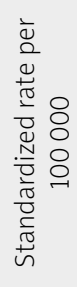 \\
\hline 139751 & 14649 & 10.5 & 12.9 & 9.4 & $2002-2011$ & 4709 & 462 & 9.8 & 0.4 & 0.3 \\
\hline 12132 & 1475 & 12.2 & 12.5 & 9.0 & 2002 & 220 & 28 & 12.7 & 0.2 & 0.2 \\
\hline 11733 & 1417 & 12.1 & 12.1 & 8.9 & 2003 & 252 & 33 & 13.1 & 0.3 & 0.2 \\
\hline 12049 & 1354 & 11.2 & 11.7 & 8.7 & 2004 & 259 & 22 & 8.5 & 0.2 & 0.1 \\
\hline 13385 & 1412 & 10.5 & 12.4 & 9.2 & 2005 & 375 & 39 & 10.4 & 0.3 & 0.3 \\
\hline 13322 & 1401 & 10.5 & 12.4 & 9.3 & 2006 & 372 & 35 & 9.4 & 0.3 & 0.2 \\
\hline 14484 & 1330 & 9.2 & 11.9 & 8.8 & 2007 & 495 & 39 & 7.9 & 0.4 & 0.3 \\
\hline 14576 & 1398 & 9.6 & 12.5 & 9.3 & 2008 & 514 & 51 & 9.9 & 0.5 & 0.3 \\
\hline 15752 & 1577 & 10.0 & 14.2 & 10.3 & 2009 & 700 & 76 & 10.9 & 0.7 & 0.5 \\
\hline 15784 & 1565 & 9.9 & 14.0 & 10.0 & 2010 & 723 & 57 & 7.9 & 0.5 & 0.4 \\
\hline 16534 & 1720 & 10.4 & 15.5 & 10.8 & 2011 & 799 & 82 & 10.3 & 0.7 & 0.5 \\
\hline
\end{tabular}


The crude ratios were calculated on the basis of the data describing actual Polish population published by the Central Statistical Office (GUS) [10]. For standardized ratios the "standardized world population" was analyzed, as proposed by Segi and modified by Doll. For statistical analyses the Microsoft Excel 2010 software was utilized. Maps were prepared using Map Viewer 7 software.

\section{Results}

In the study group there were 614 of new breast cancer cases registered. The number of registered cases at 2011 was 73 , and it was $37.7 \%$ higher as compared with the year 2002. During the analyzed period of time the increase in crude and standardized incidence ratios was observed. In 2002 the crude incidence ratio was 7.7/100 000 compared to $11.5 / 100000$ in 2011. Similarly, the standardized incidence ratio in 2002 was 6.0/100 000 versus 8.4/100 000 in 2011.

In general, malignant breast cancer cases stood up for $17.9 \%$ (and $3.4 \%$ in situ BCs) of all malignant cancers diagnosed in female inhabitants of Podkarpackie during the years 2001-2011. The average percentage share of breast cancer in women under 45 years of life, in all diagnosed malignant breast cancer cases during the analyzed decade was 10.4\% in invasive stage and 13.1 in in situ stage (Table 3).

The incidence of BC in women younger than 45 years in different counties of Podkarpackie province was ana- lyzed. In the years 2002-2011 significant differences in the studied values were observed. The highest incidence ratios were observed in Przemyski county - 16.9/100 000, in Rzeszow - 16.6/100 000 and in Przemysl - 16.2/100 000. These ratios significantly exceeded the ratio for the whole province, which was 12.9/100 000. The lowest incidence was denoted in Lubaczowski county - 7.8/100 000 and Przeworski county 9.2/100 000 (Fig. 1).

During the studied decade, breast cancer most commonly was diagnosed in locally advanced stage - 45.8\% and in regional $-29.1 \%$. Slightly over $4.0 \%$ cases were diagnosed in preinvasive stage (Fig. 2). Most of the patients (70.3\%) were treated radically, 20.0\% received palliative treatment and $4.0 \%$ - symptomatic treatment (Fig. 3).

In young women in the studied period the highest percent of cases was invasive ductal carcinoma - 69.1\%, lobular carcinoma $-7.2 \%$, and the lowest - medullary carcinoma-2.2\% (Fig. 4).

Additionally, 26 cases of in situ carcinoma were analyzed, which was $4.2 \%$ of malignant cancer cases registered in the years 2001-2011 in young women. In this study group (15-44 years of age), like in the case of invasive cancer, the increase in crude and standardized incidence ratios.

In 2002 crude incidence ratio was 0.3/100 000, and in $2011-0.9 / 100$ 000. Similarly, the standardized incidence

Table 3. Incidence of breast cancer in Podkarpackie province in the years 2002-2011, in women under 45 years of age

\begin{tabular}{|c|c|c|c|c|c|c|c|c|c|c|}
\hline \multirow{2}{*}{ 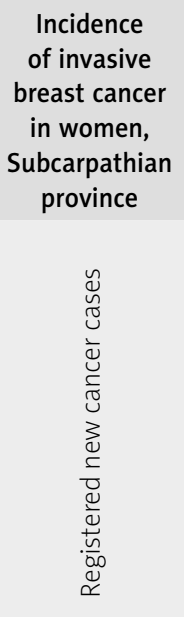 } & \multicolumn{5}{|c|}{$\begin{array}{l}\text { The incidence of invasive breast cancer } \\
\text { in women under } 45 \text { years of age, } \\
\text { Subcarpathian province }\end{array}$} & \multirow{2}{*}{ 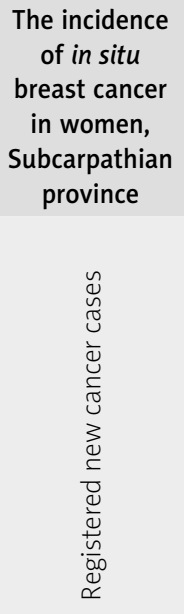 } & \multicolumn{4}{|c|}{$\begin{array}{c}\text { The incidence of in situ breast cancer } \\
\text { in women under } 45 \text { years, of age, } \\
\text { Subcarpathian province }\end{array}$} \\
\hline & 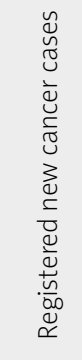 & 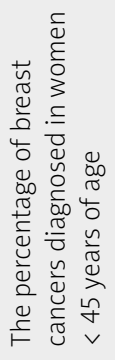 & 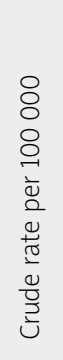 & 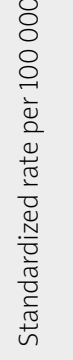 & 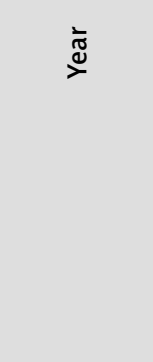 & & 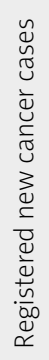 & 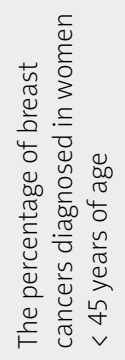 & 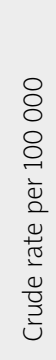 & 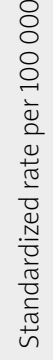 \\
\hline 5876 & 614 & 10.4 & 9.4 & 7.2 & $2002-2011$ & 199 & 26 & 13.1 & 0.4 & 0.3 \\
\hline 521 & 53 & 10.2 & 7.7 & 6.0 & 2002 & 11 & 2 & 18.2 & 0.3 & 0.2 \\
\hline 549 & 55 & 10.0 & 8.1 & 6.4 & 2003 & 12 & 0 & 0.0 & 0.0 & 0.0 \\
\hline 477 & 57 & 11.9 & 8.5 & 6.8 & 2004 & 16 & 2 & 12.5 & 0.3 & 0.3 \\
\hline 538 & 60 & 11.2 & 9.1 & 7.1 & 2005 & 12 & 2 & 16.7 & 0.3 & 0.2 \\
\hline 572 & 63 & 11.0 & 9.6 & 7.5 & 2006 & 10 & 2 & 20.0 & 0.3 & 0.2 \\
\hline 585 & 56 & 9.6 & 8.6 & 6.6 & 2007 & 29 & 2 & 6.9 & 0.3 & 0.2 \\
\hline 688 & 58 & 8.4 & 9.0 & 6.9 & 2008 & 27 & 3 & 11.1 & 0.5 & 0.4 \\
\hline 627 & 75 & 12.0 & 11.7 & 8.8 & 2009 & 24 & 4 & 16.7 & 0.6 & 0.5 \\
\hline 654 & 64 & 9.8 & 10.0 & 7.3 & 2010 & 27 & 3 & 11.1 & 0.5 & 0.3 \\
\hline 665 & 73 & 11.0 & 11.5 & 8.4 & 2011 & 31 & 6 & 19.4 & 0.9 & 0.7 \\
\hline
\end{tabular}




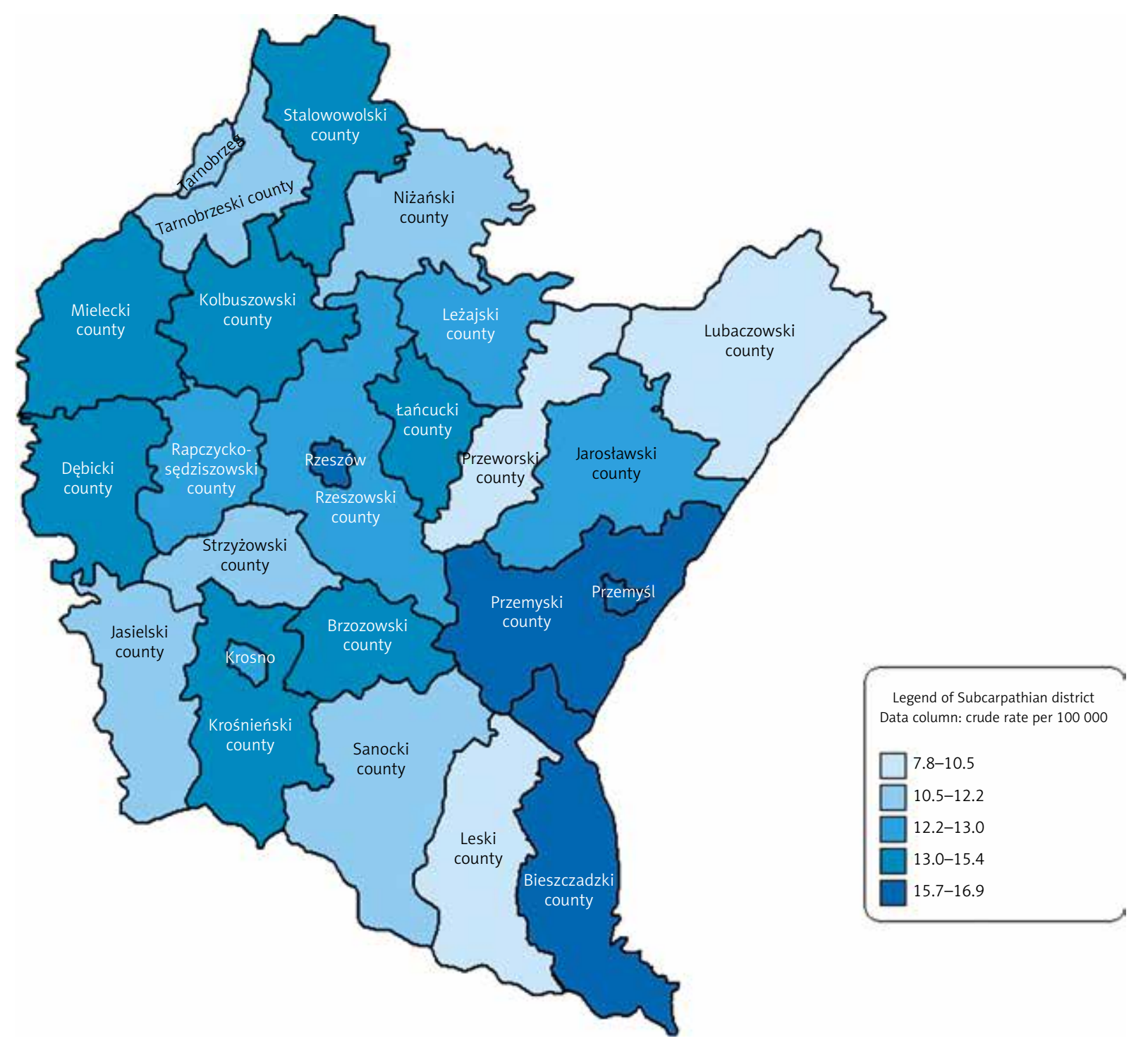

Fig. 1. The geographical distribution of the incidence of breast cancer in women under 45 years of age, in the Podkarpackie province in the years 2002-2011

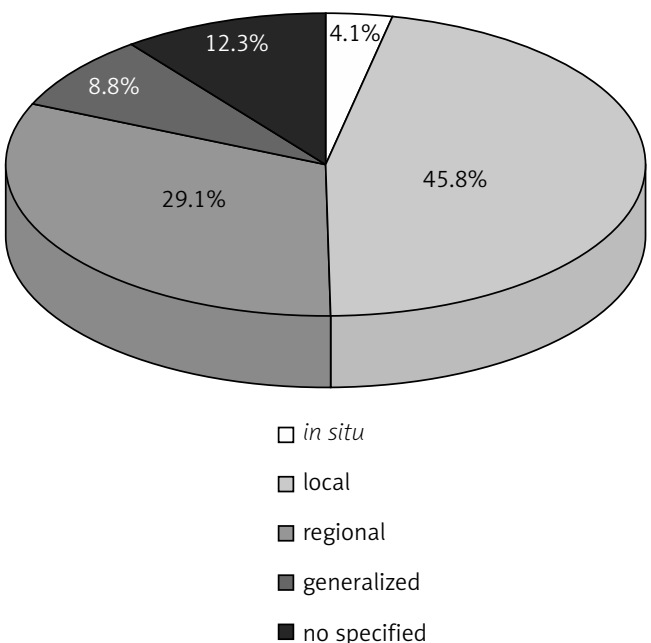

Fig. 2. Stage breast cancer in women 44 years of age at the time of diagnosis, in the years 2002-2011

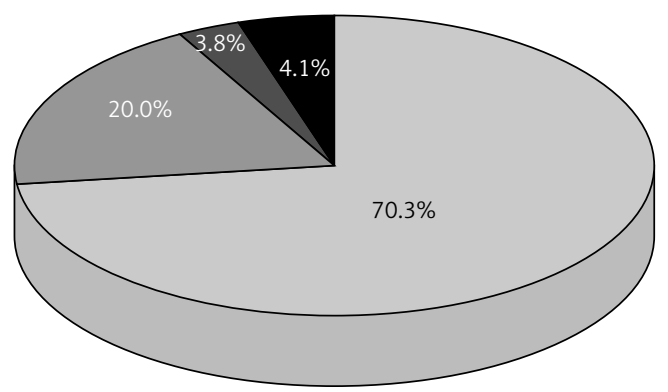

$\square$ radical

$\square$ palliative

$\square$ symptomatic

referral to treatment

Fig. 3. The type of treatment for breast cancer in women up to 44 years of age at the time of diagnosis, in the years 2002-2011 


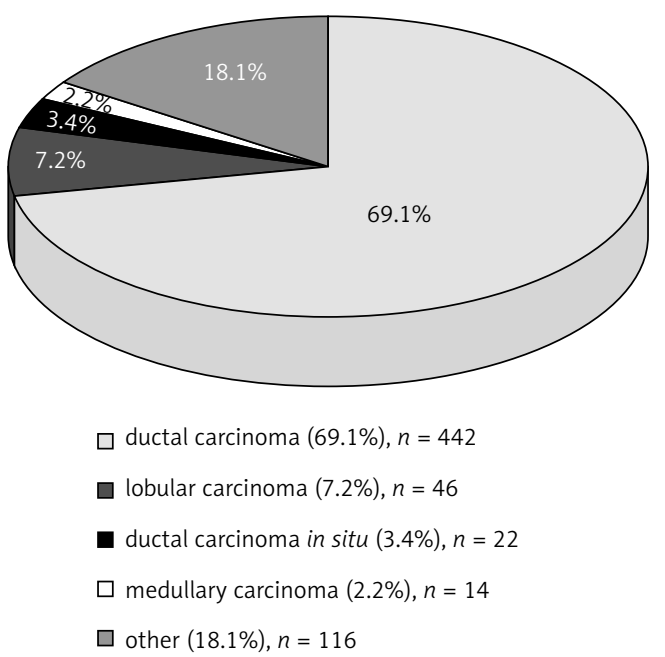

Fig. 4. Percentage of histopathological form of breast cancer in women under 45 years of age, in the Podkarpackie province, in the years 2002-2011

ratio in 2002 was $0.2 / 100000$, and in $2011-0.7 / 100000$ (Table 2, Fig. 5).

The percentage share of preinvasive breast cancer cases in all malignant cancers in the studied age group have increased by 1.4\% in 2011, as compared with 2002 (Table 2).

\section{Discussion}

Breast cancer is diagnosed most commonly in females from age group of 50-69 years, which is associated with the natural course of the disease (most cases occur after menopause) and the active diagnostic screening of this group.

Podkarpackie province is characterized by relatively low risk of BC - in 2011 its incidence was the lowest in Poland (standardized incidence ratio was 39.9/100 000). The highest ratios were denoted in western Poland, especially in Kujawsko-Pomorskie province $-60.9 / 100$ 000. The average ratio for Poland was 51.7/100 000 at that time [6, 11]. In Poland, the highest increase of breast cancer incidence was observed during the last two decades (1990-2010), mainly in women after 50 years of life. Similar tendency is observed in grown-up women before menopause (20-49 years of age), in this age group during the last three decades the incidence of BC has increased of about 1.7 times [6].

In the years 2002-2011 the increase in the number of new malignant breast cancer cases in women before 45 years of life was observed in Poland and in Podkarpackie province (16.6\% vs. $37.7 \%)$. Standardized incidence ratio during the studied decade was lower in Podkarpackie province than in Poland (7.2/100 000 vs. 9.4/100 000, respectively). The decrease in the number of diagnosed breast cancer in young women within the total number of registered breast cancer for Poland by $1.8 \%$ was observed, and for Podkarpackie province this value increased by $0.8 \%$. During the discussed decade the cumulative risk for Poland increased by $0.2 \%$, and for Podkarpackie province - by $0.1 \%$ [6].

Bleyer states, that approximately $7.0 \%$ of American women with breast cancer is diagnosed before 40; BC

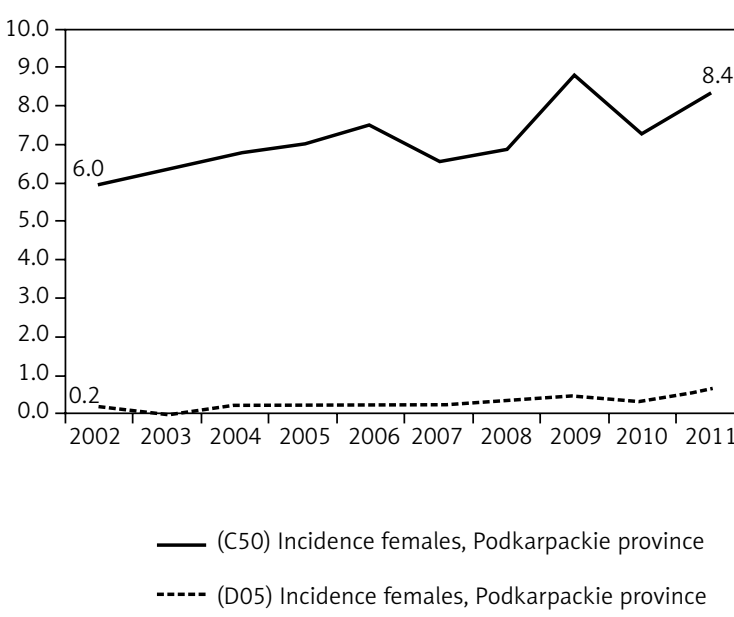

Fig. 5. Standardized incidence ratio for invasive breast cancers and preinvasive BC, in women under 45 years of age, with the Subcarpathian in 2002-2011

stands for over than $40.0 \%$ of all cancers in this age group. Survival ratios are lower as compared to older women, and multivariate analysis showed that patients' younger age is an independent poor prognostic factor [12].

In the study presented by Anders and coworkers, which was focused on gene expression in two age groups (females younger than 45 and over 65 years of age), 367 genes were identified, which might differentiate tumors of young women with lesions found in women older than 65 . The results confirm that breast cancer in patients before 45 is biologically different when compared to tumor diagnosed in females over 65 years of age [7].

During the discussed period of time, $11.0 \%$ of malignant cancers were diagnosed in females older than 45 . The increase in the incidence in the study group may be directly associated with changes which have occurred in female age structure between years 2001 and 2011.

In 2011 in Podkarpackie the increase of average 10.6 thousand in the number of women aged 25 to 39 was observed, as compared with 2002. Similar situation was in Poland as a whole, where the increase was of 227.6 thousand. Women born during the population boom (19701989) are now at increased risk of breast cancer (Figs. 6, 7).

There is significant variation in incidence of malignant breast cancer in young women in Poland. In the years 20022011 the highest incidence was denoted in Wielkopolskie (11.6/100 000), Zachodniopomorskie (10.3/100 000) and Kujawsko-Pomorskie (10.2/100 000) voivodeships. The lowest incidence was observed in Podkarpackie (7.2/100 000), Opolskie (7.8/100 000) and Lubelskie (8.6/100 0000). The average for Poland was 9.4/100 000 [6].

In Podkarpackie there is also regional variation observed - the highest incidence is typical for women residents of big towns and Bieszczady region, and the lowest charcterizes population inhabiting northeast part of the voivodeship. According to data presented by Zielińska et al., published in the report "Zdrowie kobiet w Polsce", the threat to life of women aged 15-49 in Poland after 1991 is over than 10\% 


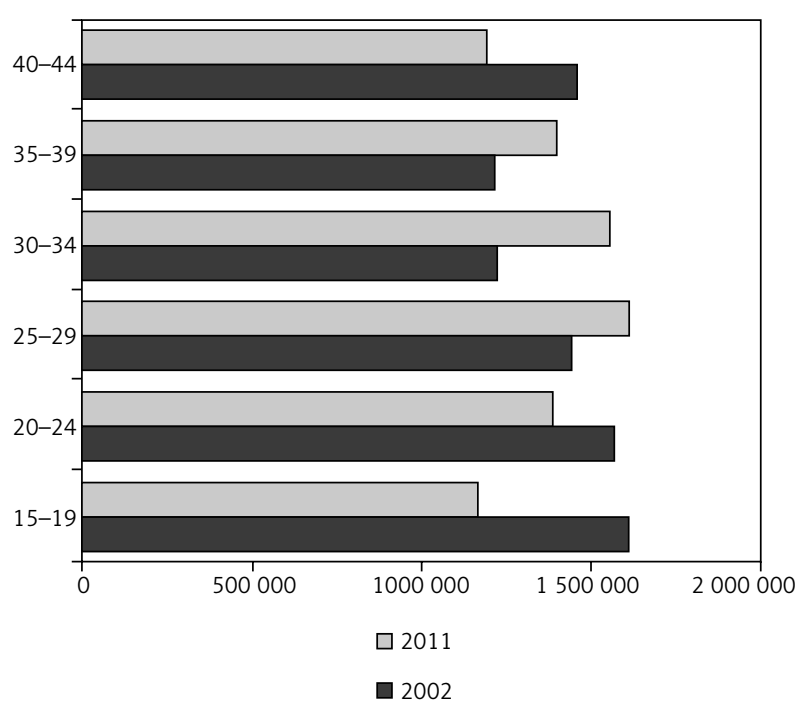

Fig. 6. The population of the Polish women < 45 years of age, in 2002 and 2011 [4]

higher in these living in towns when compared to females living in the country [13]. There is no data available, concerning life threats of women from Podkarpackie.

In Podkarpackie province the breast cancer was diagnosed most commonly as locally advanced (45.8\%). The percentage of cancer lesions identified at this stage was 9.8\% higher in 2011 than in 2002. The increase in the number of cases diagnosed as in situ (1.2\%) and disseminated disease $(1.3 \%)$ was observed. It is alarming, that in young women only $4.1 \%$ of breast cancer cases is diagnosed at in situ stage, and for approximately $9 \%$ of females the first contact with the oncologist occurs when the disease is at metastatic stage.

Low number of cancer cases diagnosed in the preinvasive stadium may be associated with low oncologic watchfulness of both women and primary care physicians. Starting from 2012 in Podkarpackie province the Conference "Early diagnostics is a chance for cure" is organized. It is addressed to primary care physicians and aimed on the increase of oncologic watchfulness. The belief that cancer is preserved for older people results with late diagnosis, when the tumor burden is substantial and the disease has spread to lymph nodes or to distant locations [14, 15].

Very important for breast cancer diagnostics is physical examination (palpably), because $80 \%$ of all lesions and $37 \%$ of malignant lesions are diagnosed this way [16].

However, Brodersen et al. state, that regular self-examine of breast doubles the number of biopsies not influencing the reduction of morbidity of breast cancer, so one can not unambiguously state that it is useful in the early detection of cancer lesions [17].

Screening towards breast cancer in young women is not indicated, especially by the use of mammography. WHO clearly points the risk associated with mammography [18]. The high density of breast tissue with the glandular component hinders the diagnostics of breast cancer in patients before 45 years of life. In genetically predisposed woman the specialists recommend annual physical exam-

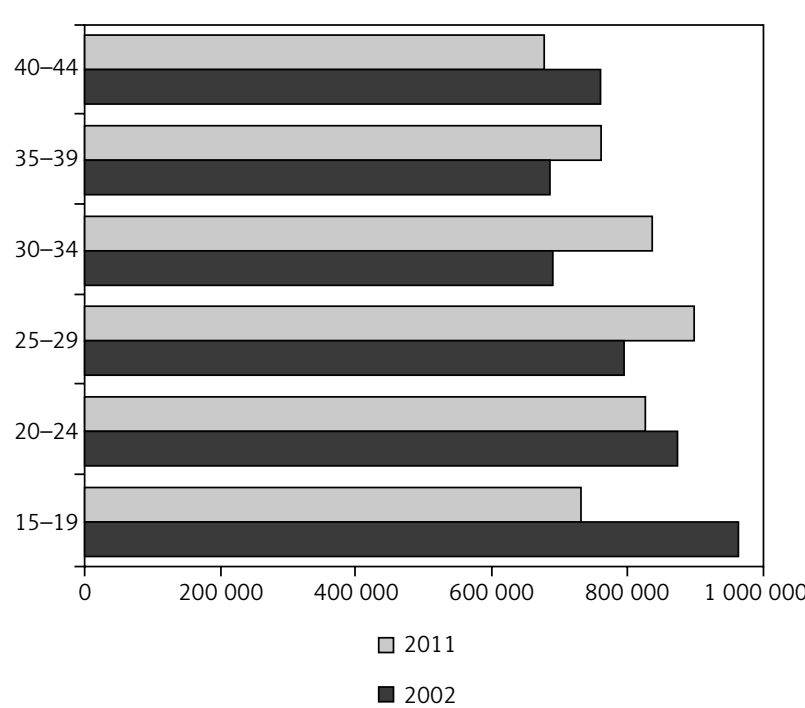

Fig. 7. The population of the Subcarpathian women < 45 years of age, in 2002 and 2011 [4]

ination and diagnostic imaging of breast (sonography in young women) starting from 20-25 year of life, mammography and sonography after 35 , and mammography every second year for women older than 50 [19].

Polish Society of Oncology recommends magnetic resonance imaging (MRI) as the most accurate diagnostic imaging method for young women from the increased risk group [20]. It was shown that MRI has significantly better resolution as compared to sonography and mammography, but as the expensive method it is nowadays used mainly for the exclusion of breast cancer suspicion [21].

The almost $10 \%$ increase in diagnoses at the locally advanced stage, observed in Podkarpackie province, may be associated with increasing awareness of young habitants of Podkarpackie and by actions carried by some local authorities which have invited all women over 20 years of age for breast sonography free of charge.

In the years 2006-2014 The Authority of Rzeszow invited young women, aged 20-44 to program "Breast cancer prevention - breast sonography". The number of women who participated in this program during this period of time increased of $248,3 \%$. This confirms the enthusiasm of beneficiaries and the necessity of such prevention programs.

In total, for 9 years 1010 pathologic lesions including 15 malignant cancers were identified in young women from Rzeszow. The amount of financial measures expended from Town Budged for this purpose was equal 211833,2 PLN (Table 4) [22].

While analysing the data concerning the incidence of breast cancer in Podkarpackie province and in Poland the substantial share of preinvasive cancers was found in young women during the discussed decade. The number of BC cases diagnosed at in situ stage in Podkarpackie province was higher than in Poland (13.2 vs. 10.1, respectively). There were no differences in case of invasive cancer.

During the analyzed period of time in Podkarpackie $70.3 \%$ of women were treated radically and in $20 \%$ of 
Table 4. Data on the implementation of the "Prevention of breast cancer - breast ultrasound", in Rzeszow, in the years 2006-2014 [22]

\begin{tabular}{|c|c|c|c|c|c|c|c|}
\hline Year & $\begin{array}{l}\text { Duration } \\
\text { of the program } \\
\text { in months }\end{array}$ & $\begin{array}{c}\text { The number } \\
\text { of tests } \\
\text { performed }\end{array}$ & $\begin{array}{l}\text { Number } \\
\text { of detected } \\
\text { lesions }\end{array}$ & BAC & Malignancy & $\begin{array}{l}\text { Patients facing } \\
\text { in-depth diagnostics }\end{array}$ & $\begin{array}{l}\text { The amount } \\
\text { of expenditure, the } \\
\text { City of Rzeszow }\end{array}$ \\
\hline 2006 & $V-X I I$ & 201 & 48 & - & 3 & 4 & 8040,0 PLN \\
\hline 2007 & $\| I-X||$ & 450 & 101 & - & 1 & 10 & 18000,0 PLN \\
\hline 2008 & $\|I-X\|$ & 589 & 125 & - & 4 & 21 & 23650,0 PLN \\
\hline 2009 & $\| I-X||$ & 457 & 88 & - & 4 & 7 & 18280,0 PLN \\
\hline 2010 & $\|-X\|$ & 560 & 90 & 8 & 0 & 12 & 23600,0 PLN \\
\hline 2011 & $\|-X\|$ & 560 & 114 & 12 & 0 & 0 & 24200,0 PLN \\
\hline 2012 & $\|-X\|$ & 554 & 123 & 20 & 1 & 14 & 26818,2 PLN \\
\hline 2013 & $\|-X\|$ & 641 & 153 & 19 & 2 & 5 & 32265,0 PLN \\
\hline 2014 & $|-X| \mid$ & 700 & 168 & 11 & 0 & 1 & 36980,0 PLN \\
\hline
\end{tabular}

$B A C-$ needle aspiration biopsy

Table 5. Survival rates relative 5-year breast cancer, young women in selected European countries (2000-2007) [26]

$\begin{array}{lcl}\text { Country } & \text { Age Class } & \text { RSC } \\ \text { France } & 15-44 & 89.2 \\ \text { Germany } & 15-44 & 87.1 \\ \text { Czech Republic } & 15-44 & 84.4 \\ \text { Slovakia } & 15-44 & 80.7 \\ \text { Poland } & 15-44 & 80.2\end{array}$

cases palliative treatment was administered. Voogd et al. have shown that in women before 35 years of age, in whom breast conserving therapy was applied, nine times higher risk of relapse was observed, as compared with patients after 60. Yet young patients treated with radical mastectomy had no increased risk of relapse, contrary to women after 60 years of age [23]. Studies performed by Bharat et al. confirm that the risk of breast cancer relapse in women diagnosed before 40 is 1.5 times higher than in patients diagnosed after that age. Risk of relapse in women of 35 in whom breast-conserving therapy was applied is 9.2 times higher than in patients aged 65+ [24]. In young women treated because of breast cancer there in an increased risk of the second breast cancer development [14]. Retrospective cohort studies performed in Denmark on 10356 females with breast cancer confirmed that in women younger than 35 at diagnosis there was the highest risk of developing metastases to lymph nodes (51\%, $p=0.02$ ), as compared to patients aged between 35 and 50. Danish studies have also shown that in young women diagnosed at the early stage of the disease, who were not treated with cytotoxic drugs, there was higher risk of death as compared with patients from older age groups. Yet patients who did not menstruate as the result of chemotherapy and ovary hormone activity suppression had better prognosis than patients menstruating normally. However, this type of the therapy is controversial because of its influence on patients' fertility [23].

The independent study, performed on 732 patients with non-metastatic breast cancer from Mount Sinai
Medical Center in New York have shown that tumors in females younger than 36 years of age were characterized by longer diameter [1].

Despite the substantial progress observed in medicine, improvement in access to diagnostic procedures and increasing awareness, which among others resulted from prophylactic actions, 5-years survival rates of young Polish women with breast cancer are the lowest in Europe (Table 5) $[25,26]$.

The study performed in Institute Curie in France have shown that even if the tumor burden, lymph node status, histological grade, hormone receptor status, local treatment procedure and systemic adjuvant treatment were considered, still the relative survival ratios were the lowest in young age group [27].

In the available bibliography there are controversial information concerning the role of oral contraception (OC) in breast cancer development induction in young patients. OC is the main contraception method in United States. More than 45 millions of American women have used OC, and 10.7 millions uses this method nowadays [28]. The study performed by Hunter et al. in 1989-2001, on the group of 116608 nurses aged 25-42 showed only slightly increased risk of cancer development in OC users $-1.33 \%$. The increase of relative risk of $3.1 \%$ was observed only in females receiving triphase preparation of levonorgestrel, which includes high doses estrogen or progesterone [29].

The incidence of breast cancer is also observed in pregnant women, occuring in 1/3000 - 1/10 000 cases, which is approximately $3 \%$ of all breast cancer cases. The physiologic changes within breast during gestation result in diagnosis delay of 5-7 months. However, the probability of metastases identification increases, it is approximately 2.5 times higher in pregnant woman as compared to the whole female population, and the presence of metastases to regional lymph nodes manifests in as many as $60 \%$ of cases [30].

Genetic predispositions, involving germinal mutations within highly penetrant genes like BRCA1 and BRCA2, is associated with the increased incidence of breast cancer 
in young women. It is thought that in $5.9-12.4 \%$ patients younger than 35 and in $11.6-17 \%$ patients before 40 years of age, there is a mutation of BRCA1 or BRCA2. In females over 40 mutations are found in $1.2 \%$ to $6.1 \%$. In selected ethnic groups, i.e. Ashkenazi Jews, BRCA mutations are identified in 29.3-44.4\% young women. Among Asian females younger than 35 ages of life the carriers of mutations constitute $8.1 \%$ [7]. Malone and coworkers state that breast cancer diagnosed before 35 years of age with high probability indicates BRCA1/2 mutations and TP53 mutations. In control studies they estimated, that $9.4 \%$ of breast cancer patients diagnosed before 35 were the carriers of BRCA1/2 mutation. The numbers are even higher in the case of familial predisposition to breast and ovarian cancer, and in women of Ashkenazi Jewish origin [31].

No matter the age of a patient and the reason of malignant cancer, such diagnosis is always a great shock for women, and carries serious medical, social, psychic and sxual consequences. For young women the international organization was created: "Young Survival Coalition". The aim of this organization is to increase awareness and to guarantee financial measures for treatment of females younger than 40 years of age. With the help of Coalition young patients may track the local support groups and participate in programs aimed on the reduction of sense of isolation and alienation from the society [32].

In conclusion, the incidence of malignant breast cancer in Podkarpackie still increases, albeit voivodeship is the region characterized by the lowest risk of developing breast cancer.

Despite the progress in diagnostics and treatment, young women are still diagnosed too late.

It is relevant to carry the information actions among women and health professionals to let them know that breast cancer may affect young women.

The interest in preventive medical examination towards breast cancer was observed in young women from Podkarpackie province.

Intensified clinical analysis of young women with breast cancer may contribute to the improvement of diagnostics and treatment in this age group.

High incidence ratios among young women may reflect the lack of routine screening in this age group, which is not enrolled into breast screening plan.

\section{The authors declare no conflict of interest.}

\section{References}

1. Gabriel CA, Domchek SM. Breast cancer in young women. Breast Cancer Res Treat. 2010; 12: 212-7.

2. http://globocan.iarc.fr (22.01.2015).

3. American Cancer Society. Breast Cancer Facts \& Figures 20112012. Atlanta: American Cancer Society; 2011.

4. American Cancer Society. Breast Cancer Facts \& Figures 20132014. Atlanta: American Cancer Society; 2013.

5. Ministry of Health and Welfare. Annual Report of Cancer Statistics in Korea in 2011. Goyang: Korea Central Cancer Registry; 2012.

6. Wojciechowska U, Didkowska J. Zachorowania i zgony na nowotwory złośliwe w Polsce. Krajowy Rejestr Nowotworów, Centrum
Onkologii-Instytut im. Marii Skłodowskiej-Curie. Available at: http://onkologia.org.pl/raporty/ (22.01.2015 r.).

7. Han-Byoel L, Wonshik H. Unique Features of Young Age Breast Cancer and Its Management. J Breast Cancer. 2014; 17: 301-307.

8. Goldhirsch A, Winer EP, Coates AS, et al. Personalizing the treatment of women with early breast cancer: highlights of the St Gallen International Expert Consensus on the Primary Therapy of Early Breast Cancer 2013. Ann Oncol. 2013; 24: 2206-2223.

9. Zabicki K, Colbert JA, Dominguez FJ, et al. Breast cancer diagnosis in women 40 versus 50 to 60 years: Increasing size and stage disparity 67 compared with older women over time. Ann Surg Oncol. 2006; 13: 1072-1077.

10. http://stat.gov.pl (22.01.2015 r.)

11. Grądalska-Lampart M, Radziszewska A, Patro A, Gawełko J. Nowotwory złośliwe w województwie podkarpackim w 2011 roku. Wojewódzki Szpital Specjalistyczny im. F. Chopina w Rzeszowie, Podkarpackie Centrum Onkologii, Zakład Epidemiologii i Podkarpacki Rejestr Nowotworów. Rzeszów 2013; 1-160.

12. Bleyer A, Barr R, Hayes-Lattinet B, et al. The distinctive biology of cancer in adolescents and young adults. Nat Rev Cancer. 2008; 8: 288-298.

13. Zielińska E, Nowicka W. Zdrowie kobiet w Polsce. RAPORT. Kongres Kobiet Polskich 2009, Kobiety dla Polski, Polska dla Kobiet 20 lat transformacji 1989 - 2009, Fundacja Feminoteka, Warszawa 2009; 271-295.

14. Partridge AH, Goldhirsch A, Gelber S, Gelber RD. Breast cancer in younger women. In: Diseases of the breast. Harris JR, Lippman ME, Morrow M, Osborne CK (eds.). $4^{\text {th }}$ ed. Lippincott Williams \& Wilkins, Philadelphia 2010; 1073-83.

15. Anders CK, Johnson R, Litton J, Phillips M, Bleyer A. Breast cancer before age 40 years. Semin Oncol 2009; 36: 237-49.

16. Tkaczuk-Włach J, Sobstyl M, Jakiel G. Rak piersi - znaczenie profilaktyki pierwotnej i wtórnej. Prz Menopauzalny 2012; 4: 343-7.

17. Brodersen J, Jørgensen KJ, Gøtzsche PC. The benefits and harms of screening for cancer with a focus on breast screening. Pol Arch Med Wewn 2010; 120: 89-94.

18. http://apps.who.int/iris/bitstream/10665/137339/1/ 9789241507936 eng.pdf?ua=1 (10.02.2015 r.).

19. Nelson HD, Tyne K, Naik A, Bougatsos C, Chan BK, Humphrey L; U.S. Preventive Services Task Force. Screening for breast cancer: an update for the U.S. Preventive Services Task Force. Ann Intern Med 2009; 151: 727-37.

20. Rekomendacje PTG dotyczące wykrywania wysokiego, dziedzicznie uwarunkowanego ryzyka zachorowania na raka gruczołu sutkowego i/lub jajnika oraz opieki nad rodzinami, w których ono występuje (2004).

21. Kreige M, Brekelmans CT, Obdeijn IM, et al. Factors affecting sensitivity and specificity of screening mammography and MRI in women with an inherited risk for breast cancer. Breast Cancer Res Treat 2006; 100: 109-19.

22. Urząd Miasta Rzeszów. Program "Profilaktyka raka piersi - badania USG piersi”, Rzeszów 2006-2014.

23. Voogd AC, Nielsen M, Peterse JL, et al. Danish BreastCancer Cooperative Group. Breast Cancer Cooperative Group of the European Organization for Research and Treatment of Cancer. Differences in risk factors for local and distant recurrence after breast-conserving therapy or mastectomy for stage I and II breast cancer: pooled results of two large European randomized trials. J Clin Oncol 2001; 19: 1688-97.

24. Bharat A, Aft RL, Gao F, Margenthaler JA. Patient and tumor characteristics associated with increased mortality in young women ( $<$ or $=40$ years) with breast cancer. ) Surg Oncol 2009; 100: 248-51.

25. Swain SM, Jeong JH, Geyer CE Jr, et al. Longer therapy, iatrogenic amenorrhea, and survival in early breast cancer. N Engl J Med 2010; 362: 2053-65.

26. http://www.eurocare.it (23.01.2015).

27. De la Rochefordiere A, Asselain B, Campana F, et al. Age as prognostic factor in premenopausal breast carcinoma. Lancet 1993; 341: 1039-43.

28. Mosher WD, Jones J. Use of contraception in the United States: 1982-2008. Vital Health Stat 2010; 23: 1-44. 
29. Hunter DJ, Colditz GA, Hankinson SE. Oral contraceptive use and breast cancer: a prospective study of young women. Cancer Epidemiol Biomarkers Prev 2010; 19: 2496-502.

30. Litton JK, Theriault RL. Breast cancer and pregnancy: current concepts in diagnosis and treatment. Oncologist 2010; 15: 1238-47.

31. Malone KE, Daling JR, Neal C, Suter NM, O'Brien C, Cushing-Haugen K, Jonasdottir TJ, Thompson JD, Ostrander EA. Frequency of BRCA1/BRCA2 mutations in a population-based sample of young breast carcinoma cases. Cancer 2000; 88: 1393-402.

32. http://www.youngsurvival.org.

\section{Address for correspondence}

Aneta U. Radziszewska

Department of Epidemiology and Podkarpackie Cancer Registry

Podkarpackie Oncology Centre

Szopena 2

35-055 Rzeszów, Poland

tel. +4817 8666221

fax +48178666 655

e-mail: radziszewska.aneta@interia.pl

Submitted: 27.03 .2015

Accepted: $\quad 30.11 .2015$ 